\title{
The Impact of Commodity Prices, Interest Rate and Exchange Rate on Stock Market Performance: Evidence from Zambia
}

\author{
Nsama Musawa, Clement Mwaanga \\ Department of Business Studies, Mulungushi University, Kabwe, Zambia \\ Email: nsama.musawa@yahoo.com,nnjebele@mu.ac.zm,cmwaanga@mu.ac.zm,mwaanga.clement@yahoo.co.uk
}

How to cite this paper: Musawa, N., \& Mwaanga, C. (2017). The Impact of Commodity Prices, Interest Rate and Exchange Rate on Stock Market Performance: Evidence from Zambia. Journal of Financial Risk Management, 6, 300-313. https://doi.org/10.4236/jfrm.2017.63022

Received: July 3, 2017

Accepted: September 19, 2017

Published: September 22, 2017

Copyright (c) 2017 by authors and Scientific Research Publishing Inc. This work is licensed under the Creative Commons Attribution International License (CC BY 4.0).

http://creativecommons.org/licenses/by/4.0/

(c) (i) Open Access

\begin{abstract}
In 2016, the performance of Capital markets in Africa experienced a downward trend. Notable among them were Zambia, Ghana and Nigeria (http://www.african-markets.com/). The Lusaka Securities Exchange (LuSE) share price index was the worst performer year-to-date, down $26.83 \%$ in local currency. Among the contributing factors cited were commodity prices as the country relies on copper for more than $70 \%$ of its export revenue and had therefore suffered from commodity prices plunged which led to weakened currencies and widened budget shortfalls (http://www.african-markets.com/). Although the contributing factors are known, their impact on the Zambian stock market is not known. This study was an attempt to establish the impact of commodity prices and macroeconomic factors on the stock market returns. Like in similar studies, Nordin et al. (2014) and Alam \& Uddin (2009), we used Auto regression Distribution Lag and Cointegration analysis and the Vector Error Correction model on the variables (stock price index, copper price, oil price, interest rates, and exchange rates) for the period 2004-2016. The findings of the study revealed Interest rates, exchange rates, copper and Oil price jointly have the long and short Run impact on the Lusaka Stock Market, but individually, only interest rates and copper prices had a significant long term impact on the stock market, but in the short run only Copper and Exchange rates had an immediate impact on the stock market. One important policy implication of this study is that it will alert the authorities and the investors on the impact of commodity prices, interest rate, and the exchange rate on the Lusaka Securities Exchange stock market performance.
\end{abstract}

\section{Keywords}

Stock Price Index, Commodity Prices, Interest Rates, Exchange Rates, Cointegration 


\section{Introduction}

In the early 2000's the world witnessed a remarkable increase in the world oil and metal prices and the decline in the value of the US dollar (Rezitis, 2015). The commodity, usually acts as input to most of the production process and has the capacity to affect the outputs which in turn affect the performance of the stock markets. It has been observed that a stock market plays a pivotal role in economic growth through enhanced domestic savings and increased quantity and quality of investment (Nordin et al., 2014) and the development of the nation. In Sub-Sahara African Countries are characterised by being small and have a major scale of inefficiencies. Although some measures have been put in place to strengthen financial instruments over the past decade, they are still facing the challenges such as how to increase liquidity, expand access and reduce the cost capital (Odera, 2012).

The Lusaka stock Exchange (LuSE) is not an exception in terms of performance as compared to other stock markets in Sub-Sahara African Countries. The share price index of LuSE is declined in 2016 by an average of 26.83 in local currency as shown in Table 1 below (http://www.african-markets.com/).

For instance the all-share index at the end of 2015 recorded a $6.91 \%$ decline in Kwacha terms and $45.75 \%$ in USD terms and the Market capitalisation on the LuSE closed the year at ZMW 64.3bn or US $\$ 5.9 \mathrm{bn}$, compared with the 2014 close of ZMW 66.7bn or US\$10.5bn (Southern African. News). The poor results were attributed to over dependency on copper, increase in the price of oil and

Table 1. Key markets 2016 performance.

\begin{tabular}{cccc}
\hline Selected Market & Index Name & Local \% chg & 2016 Returns USD \% chg \\
\hline Botswana & BSE DCI & -11.33 & -6.80 \\
Egypt & EGX 30 & 76.20 & -25.55 \\
Ghana & GSE-CI & -15.33 & -24.55 \\
Kenya & NSE ASI & -8.48 & -9.01 \\
Mauritius & SEMDEX & -0.15 & -0.56 \\
Morocco & MASI & 30.46 & 27.94 \\
Malawi & MSE ASI & -8.53 & -15.26 \\
Namibia & MSE ASI & 23.47 & 39.66 \\
Nigeria & NGSE ASI & -6.17 & -40.63 \\
Rwanda & RSE ASI & -2.56 & -13.21 \\
South Africa & JSE ASI & -0.08 & 12.52 \\
Tanzania & DSE ASI & -5.80 & -7.44 \\
Tunisia & TUNINDEX & 8.86 & -3.47 \\
Uganda & USE ASI & -16.24 & -21.92 \\
Zambia & LuSE ASI & -26.83 & -19.18 \\
Zimbabwe & ZSE Ind. & 25.84 & 25.84 \\
\hline & & & \\
\hline
\end{tabular}


the interest and exchange rate fluctuations.

Therefore, this study was an attempt to establish the impact of macroeconomic factors and the commodity prices on the performance of stock returns. Specifically, this study investigated whether the LuSE returns are affected by the oil price, copper price, interest rate and exchange rate fluctuations.

The copper price was included in this study because, in Zambia copper accounts for $70 \%$ of the country's expert revenue and has continued to suffer from a decrease in price at the London Metal Exchange. The decrease in the price of copper has weakened the strength of the currency and widened the budget deficit.

The inclusion of the oil price was based on the fact that oil is one of the major inputs to the manufacturing industry. According to Economic Commission for Africa (2016), manufacturing sector in Zambia contributes about 7.9\% on average of the countries GDP, while oil accounts for $14 \%$ of the countries total imports. The other factor considered about oil price is its ability to cause inflation and suppress people's consumption and investment (Cong, Wei, Jiao, \& Fan, 2008).

The other two macroeconomic factors (interest rate and exchange rate) were included in this study because they have been widely associated with changes in performance of the stock returns in most studies (Mahmudul, 2009; Nordin et al., 2014; Rezitis, 2015). These studies have been done in developed countries, hence the need for this study to apply them in developing country context, Zambia to be specific.

In sum, this study was an attempt to investigate the following: a) the impact of commodity prices (copper and oil prices) on the performance of LuSE market, b) the impact of the macroeconomic factors (interest and exchange rates) on the performance LuSE market and c) the impact of commodity prices and macroeconomic factors on the performance of LuSE market.

This study contributes to the empirical literature on the relationship between the commodity prices, macroeconomic factors, namely the interest and exchange rates and the LuSE stock returns. These variables have been studied in isolation (Mahmudul, 2009; Nordin et al., 2014; Rezitis, 2015) and in developed country context, therefore this study attempted to look at the impact of the four variables on the LuSE stock market performance. The findings will also help authorities and investors to assess the implication of commodity prices and macroeconomic factors fluctuations on the Zambia's economic growth.

\section{Literature Review}

Research on the performance of the stock markets has gained popularity among scholars and politicians. This section will present a short review of the literature on the effects of commodity prices and macroeconomic factors, namely interest rate and exchange rate on the stock market performance.

A number of studies carried out in this area have revealed different results due 
to the period of study, study context and the methodologies used (Nordin et al., 2014). Different commodity prices and macroeconomic factors have been applied to assess their impact on stock market performance and also different time periods (either yearly or monthly).

An early study done by (Strieborny \& Olsen, 2014) explained the significance of using oil price and established the relationship between oil price and the stock market performance. He suggested that oil price is an important commodity price because of its ability to influence other variables. However a study done by (Cong et al., 2008) found no significant relationship between the oil price and stock market performance in China. In addition, a recent in Turkey suggested that there is no relationship between commodity prices and the stock prices (Erphen, 2014).

In South America, the study carried out by Soenen \& Johonson (2009) revealed a strong relationship between commodity prices and the stock market performance employing the interest and exchange rates as the controlling variable.

In a similar vain, Nordin et al. (2014) examined the impact of commodity prices (palm oil price and gold price), interest rate and exchange rate on the Malaysian stock market performance. Using the bound test approach which showed the cointegration relationship between the variables, the findings revealed that the palm oil price had significant influence on the stock market performance. However, the results showed no influence for both palm oil price and gold price, but significant influence for both interest rate and exchange rate. But the earlier studies conducted in Malaysia by Rahman et al. (2009) and Mahmood \& Mahd Dinniah (2009) showed no relationship between macroeconomic variable namely interest rate and exchange rate and the stock prices.

\section{Data and Methodology}

This study employed Auto Regression Distribution Lag (ARDL) bound tests, Vector Auto Regression (VAR) based cointegration test methodology by Johansen (1996) to analyse the Impact of the commodity prices (copper price and oil price), macroeconomic variables (interest rate and exchange rate) and the LuSE price index in Zambia. The data on copper price (US Dollar per ton), oil price (US Dollar per barrel), weighted average landing interest rate and Real Exchange Rate were collected from the Bank of Zambia while the data on the price index was collected from the Lusaka Stock Exchange (LuSE). Monthly data ranging from January 2004 to December 2016, covering a period of 12 years was used in this study. The period of study includes the 2008 global financial crisis. Data analysis followed five steps 1) Graphical analysis, 2) Diagnostic tests for the variables, 3) Lag length selection, 4) cointegration test and 5) Auto Regression distribution lag bound tests.

\section{Results}

This section shows how graphical analysis and econometric models were used to 
analyse the data on the LuSE price index, Interest rates, and Exchange rate, Copper and oil prices. The graphic analysis compares the dependent variable (LuSE price index) and each of the four independent variables (Interest rates, Exchange rate, Copper and oil prices).

\section{Graphical Analysis}

The graphical analysis was conducted to show the potential impact of commodity prices, interest rate and exchange rate on the LuSE price index.

\section{LuSE Price Index and Interest Rate}

A graphical analysis of the data on LuSE Price Index and Interest Rate gave the results shown in Figure 1 below. The luSE index had an upward trend while the interest rates should a downward trend. They both move around the non Zero or constant point. This simply means that the variables might not be stationary. As can be observed from the graph the stock index and the interest rates moved in opposite direction they have a negative relationship. The stock index was at its highest pick in 2014-2015 but thereafter started to decrease. This pattern is similar to what was observed 2007 to 2009.

\section{LuSE Price Index and Copper Price}

A graphical analysis of the data on LuSE Price Index and Copper price gave the results shown in Figure 2 below. They both have an upward trend and move around the non Zero or constant meaning the variables might not be stationary. As can be observed from the graph the stock index and the Copper price move in the same direction which shows that they have a positive relationship.

\section{LuSE Price Index and Real Effective Exchange Rate (REER)}

A graphical analysis of the data on LuSE Price Index and Exchange Rate (REER) is shown in Figure 3 below. While the LuSE index had an upward trend the exchange rates seem to be stable. They both move around the non Zero or

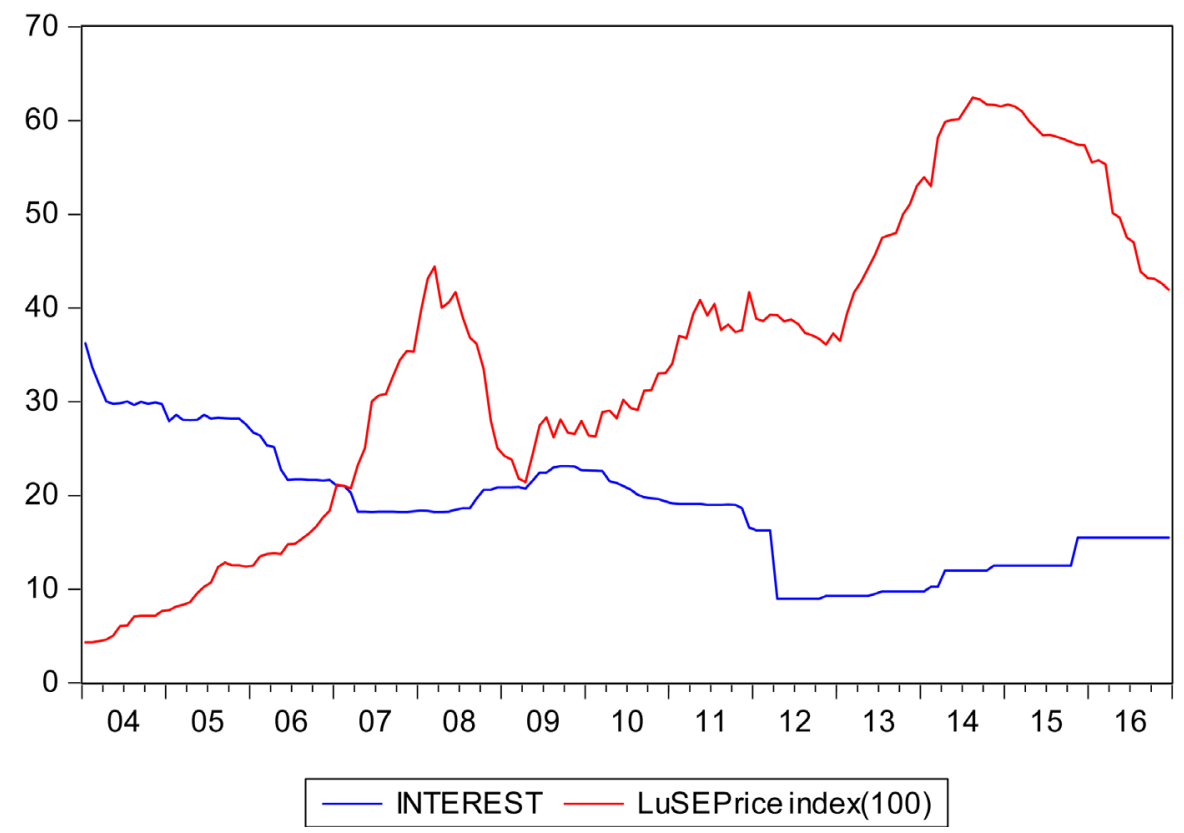

Figure 1. Price index and Interest rates. 


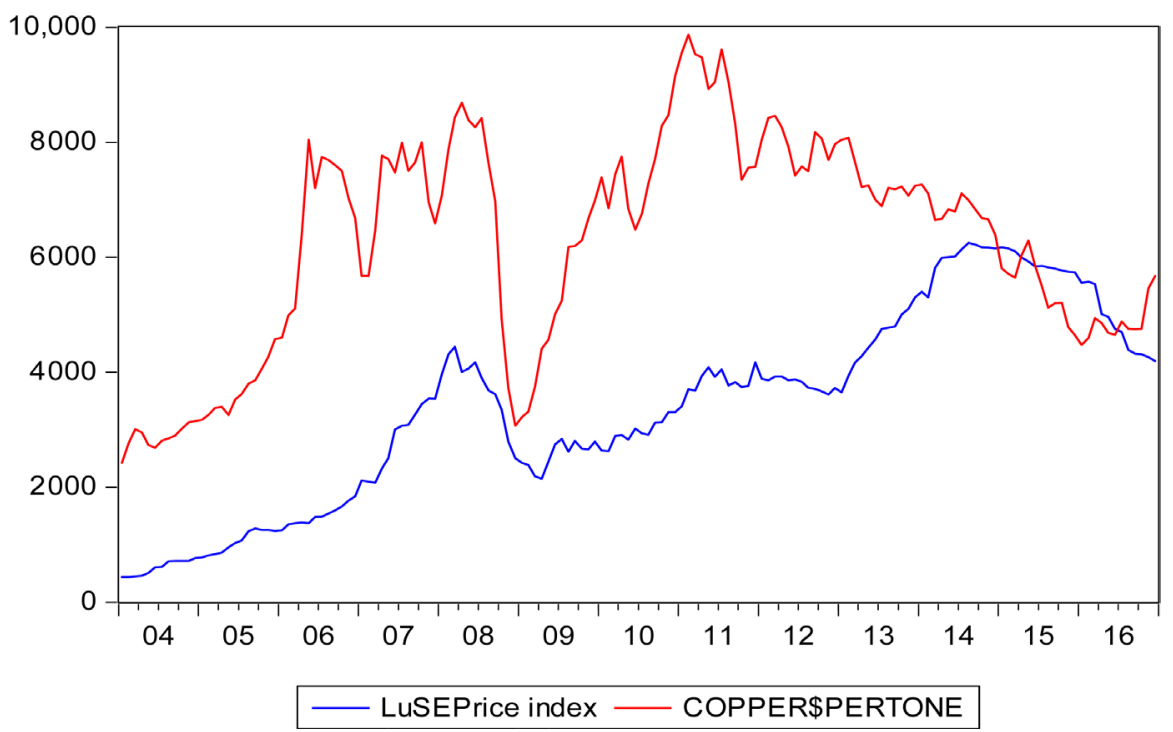

Figure 2. Graphs showing the LuSE Price index and the Copper price.

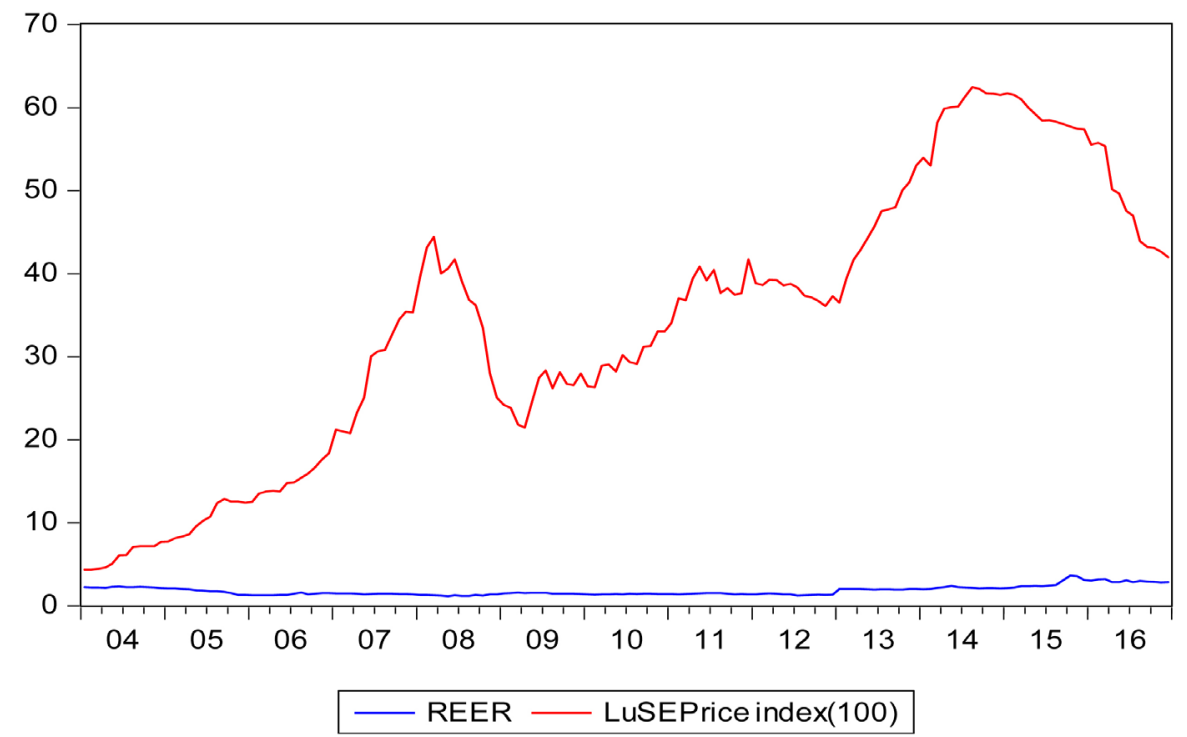

Figure 3. LuSE Price index and Real Effective Exchange.

constant meaning the variables might not be stationary.

\section{LuSE Price Index and Oil Price}

A graphical analysis of the data on LuSE Price Index and Oil price gave the results shown in Figure 4 below. They both have an upward trend and move around the non Zero or constant meaning the variables might not be stationary. As can be observed from the graph the stock index and the Oil price move in the same direction which shows that they have a positive relationship.

\section{Econometric Modelling}

Like in similar research studies, Nordin et al. (2014) and Alam \& Uddin (2009), this research utilized the Auto Regression Distribution Lag (ARDL) bound tests, Vector Auto Regression (VAR) based cointegration test methodology by Johansen (1996) to analyse the Impact of Interest rate, Exchange rate and 


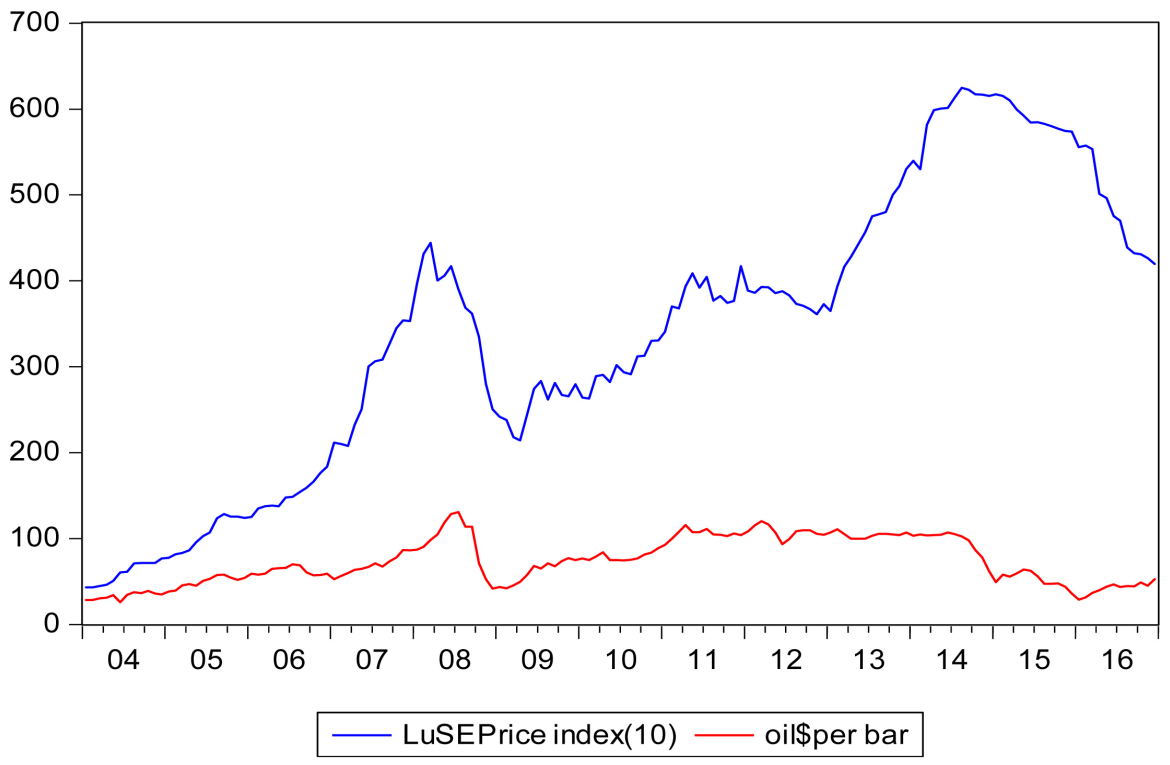

Figure 4. LuSE Price index and the oil.

commodity prices (Copper and oil) on the stock market in Zambia.

\section{Diagnostic Tests}

Before the estimation was done some diagnostic tests were done among them was the normality test for the dependent variable, Multicollinearity of independent variables and the Unit root test.

\section{Normality of Dependent Variable}

A very important assumption in regression is that the dependent variable is normally distributed. A test whether the frequency distribution of the variable deviates from a normal distribution was done using Jarque-Bera statistics. If the Jarque-Bera probability test is non-significant ( $p>0.05)$, it tells that the distribution in the sample is not significantly different from a normal distribution (Field, 2005). The Jarque-Bera statist of 5.9063 with the probability of 0.0521 was observed, indicating that the LuSE Price Index was normally distributed.

\section{Correlations and Multicollinearity}

Before presenting the regression models, one should inspect if there are excessive correlations between the independent variables in the model. The correlation matrix can be scanned as a preliminary look for multicollinearity. To avoid multicollinearity in the sample, there should be no substantial correlations $(\mathrm{R}>$ 0.9 ) between the predictors or independent variables (Field, 2005). The correlation matrix in Table 2 shows that there were no variables that had excessive correlations between them.

\section{Unit Root Test}

Before the estimation was done, the unit root test was performed to confirm the stationary properties of the data and in order to understand the order of integration of the variables into the long run equation.

Ascertaining stationary property of data is vital in time series. Carrying out estimation without establishing whether data is stationary or not is equivalent to 
Table 2. Correlation statistics of independent variables.

\begin{tabular}{ccccc}
\hline & Interest rate & REER & Copper price & Oil price \\
\hline Interest rate & 1 & -0.18 & -0.55 & -0.58 \\
REER & -0.18 & 1 & -0.47 & -0.48 \\
Copper price & -0.55 & -0.47 & 1 & 0.84 \\
Oil price & -0.58 & -0.48 & 0.84 & 1 \\
\hline
\end{tabular}

Source: Generated by the authors (2017).

Table 3. Unit Root Test.

\begin{tabular}{|c|c|c|c|c|c|}
\hline \multirow{3}{*}{ Description } & \multicolumn{4}{|c|}{ Differencing } & \multirow{3}{*}{$\begin{array}{l}\text { Order of } \\
\text { integratior }\end{array}$} \\
\hline & \multicolumn{2}{|c|}{ Levels } & \multicolumn{2}{|c|}{ First difference } & \\
\hline & t-value & $P$-value & $t$-value & $P$-value & \\
\hline LuSE index & -2.0779 & 0.5535 & -4.5611 & 0.0017 & $\mathrm{I}(1)$ \\
\hline Interest & -1.9092 & 0.6449 & -11.30948 & 0.0000 & $\mathrm{I}(1)$ \\
\hline REER & -1.941974 & 0.0540 & -9.9055 & 0.0000 & $\mathrm{I}(1)$ \\
\hline Copper & -2.448232 & 0.3535 & -8.764907 & 0.0000 & $\mathrm{I}(1)$ \\
\hline \multirow[t]{2}{*}{ Oil } & -2.205665 & 0.4827 & -8.734331 & 0.0000 & $\mathrm{I}(1)$ \\
\hline & $1 \%$ level & -4.019561 & & & \\
\hline \multirow[t]{2}{*}{ Test critical values: } & $5 \%$ level & -3.439658 & & & \\
\hline & $10 \%$ level & -3.144229 & & & \\
\hline
\end{tabular}

assuming that time series data is stationary, implying that it's mean, variance and autocovariance remain constant over time (Gujarati, 2003).

However, time series data in most cases may not be stationary implying that the mean, variance and the auto covariance of such data may not be constant over time and therefore, regression results from such estimation may be spurious or wrong. After establishing stationary property of the data, cointegration test was performed to establish the long run relationship of the variables.

The results of the unit root tests using the Augmented Dickey-Fuller (ADF) tests based on trend and intercept are presented in below.

If the data is stationary (has no unit root) the $t$ value, should be greater than the critical values in absolute terms and the $p$ value should be significant (less than 0.05) as shown in Table 3.

The results show that:

The LuSE index has a unit root (not stationary) because the ADF statistic ( $\mathrm{t} \alpha$ ) 2.0779 is not greater than the critical values of 4.0195, 3.4396 and 3.1444 at all the levels of significant (1\%,5\% and $10 \%)$ and the $P$ value of 0.5535 is not significant, but after the first differencing it becomes stationary as ( $\mathrm{t} \alpha$ ) 4.5611 is greater than all the critical values of 4.5611, 4.0195 and 3.1442 at all levels of significance and the $p$ value of 0.0017 is significant thus integrated of the order one $\mathrm{I}(1)$. 
The Interest rate has a unit root (not stationary) because the ADF statistic ( $\alpha$ ) 1.9092 is not greater than the critical values of 4.0195, 3.4396 and 3.1444 at all the levels of significant $(1 \%, 5 \%$ and $10 \%)$ and the $P$ value of 0.6449 is not significant, but after the first differencing it becomes stationary as ( $\mathrm{t} \alpha$ ) 11.30948 is greater than all the critical values of 4.5611, 4.0195 and 3.1442 at all levels of significance and the $p$ value of 0.0000 is significant thus integrated of the order one $\mathrm{I}(1)$.

The Copper price has a unit root (not stationary) because the ADF statistic ( $\mathrm{t} \alpha) 2.448232$ is not greater than the critical values of $4.0195,3.4396$ and 3.1444 at all the levels of significant $(1 \%, 5 \%$ and 10\%) and the $P$ value of 0.3535 is not significant, but after the first differencing it becomes stationary as ( $\mathrm{t} \alpha$ ) 8.764907 is greater than all the critical values of 4.5611, 4.0195 and 3.1442 at all levels of significance and the $p$ value of 0.0000 is significant thus integrated of the order one I(1).

The Oil price has a unit root (not stationary) because the ADF statistic ( $\mathrm{t} \alpha$ ) 2.205665 is not greater than the critical values of 4.0195, 3.4396 and 3.1444 at all the levels of significant (1\%,5\% and $10 \%)$ and the $P$ value of 0.4827 is not significant, but after the first differencing it becomes stationary as ( $\alpha$ ) 8.734331 is greater than all the critical values of 4.5611, 4.0195 and 3.1442 at all levels of significance and the $p$ value of 0.0000 is significant thus integrated of the order one $\mathrm{I}(1)$.

\section{Long Run Estimation Based on Cointegration Analysis}

Since the variables were discovered to have unit roots meaning that they are non-stationary at the first level, but became a stationery after the first difference, a cointegration test was performed in order to test whether the variables were cointegrated or not. The presence of a cointegrating relationship means that the variables have a long run equilibrium relationship and therefore forms a basis for the Vector Error Correction specification. Three steps were followed 1) Lag length selection 2) cointegration test and 3) Auto Regression distribution lag bound tests. If the variables were found to be cointegrated.

\section{Lag Length Selection}

In the first step of establishing the lag length unrestricted Vector Auto Regression estimation was undertaken in order to come up with an appropriate lag length to be used when establishing cointegration among the variables of. A lag length of twelve was selected as an appropriate based on the sequential modified LR test statistic.

\section{Cointegration Test}

The Johansson Cointegration tests were done in the Stock Index as a dependent variable and Interest rates, exchange rates, copper and oil price as independent variables. A cointegration exists if the trace statist value is more than the critical value and the probability is significant or if the error correction variable in the Vector Error Correction model has a negative sign and significant. The results for Johansson cointegration test in Table 4 shows that there is cointegration as trace statist value or 80.6664 is more than the critical value of 69.818 and 
Table 4. Cointegration Rank Trace Test Analysis results.

\begin{tabular}{cccccc}
\hline $\begin{array}{c}\text { Cointegrated } \\
\text { Variable }\end{array}$ & $\begin{array}{c}\text { Hypothesized No. } \\
\text { of CE(s) }\end{array}$ & Eigenvalue & $\begin{array}{c}\text { Trace } \\
\text { Statistic }\end{array}$ & $\begin{array}{c}\text { 0.5 Critical } \\
\text { Value }\end{array}$ & Prob. \\
\hline & None & 0.2369 & 80.666 & 69.818 & 0.005 \\
$\begin{array}{c}\text { Stock Index, } \\
\text { Interest Rates, }\end{array}$ & At most 1 & 0.1044 & 41.986 & 47.856 & 0.159 \\
$\begin{array}{c}\text { REER, Copper } \\
\text { Price and Oil }\end{array}$ & At most 2 & 0.0992 & 26.217 & 29.797 & 0.122 \\
$\quad$ Price & At most 3 & 0.0757 & 11.277 & 15.494 & 0.195 \\
& At most 4 & 4.94805 & 0.0070 & 3.8414 & 0.932 \\
\hline
\end{tabular}

Table 5. Auto Regression distribution lag bound tests.

\begin{tabular}{ccccc}
\hline Variable & Coefficient & Std. Error & t-Statistic & Prob. \\
\hline Log LuSE Index & -0.071678 & 0.015857 & -4.520147 & 0.0000 \\
Interest Rate & -0.004520 & 0.001538 & -2.938743 & 0.0039 \\
REER & 0.007237 & 0.012225 & 0.591942 & 0.5549 \\
Copper Price & 1.144710 & 4.901767 & 2.304467 & 0.0227 \\
Oil Price & -0.000495 & 0.000320 & -1.544591 & 0.1248 \\
\hline
\end{tabular}

the probability value of 0.005 is significant. This indicates that there is a long run relationship between LuSE Index, Interest rates, exchange rates, Copper and oil price in Zambia. Similar to Soenen \& Johonson (2009), Nordin et al. (2014) and Mahmood \& Mahd Dinniah (2009).

\section{Auto Regression Distribution Lag Bound Tests}

Since the variables were found to have a long run relationship Auto Regression distribution lag bound tests was done to establish the long run coefficients. After diagnostic test the LuSE index was transformed into logs and dependant variables were lagged. Table 5 shows the results for the Auto Regression distribution lag bound tests.

From the results, the estimated coefficient for Interest is negative and statistically significant. This indicates that increase in interest has a negative effect on the stock index. This is in line with the conventional economic reasoning, when the interest rate is high, investors will shift their money from higher risk instrument which is the stock market to savings or fixed deposit accounts. On the other hand, when the interest rate is too low, investors will move the money out to invest in the stock market in the hope of getting a higher return. Similar results were found by Mahmudul \& Gazi (2009) for 15 developed and developing countries, and Nordin et al. (2014) in Malaysia.

The estimated coefficient for the exchange rate is positive but statistically insignificant as the $p$ value is 0.05549 is more 0.05 . This indicates that the exchange rate has no significant long run effect on the LuSE Index. Mixed empirical results showing the positive and negative effect of the exchange rate towards the stock market index have been found. For example Bhattacharya \& Mukherjee (2003) found no relationship. Nordin et al. (2014) found a positive relation- 
ship in Malaysia, although earlier studies conducted in Malaysia by Rahman et al. (2009), Mahmood \& Mahd Dinniah (2009) showed no relationship and Sichoongwe (2016) found a negative relation in Zambia although in his study a different methodology was used and market capitalization instead of stock price index.

The estimated coefficient for Copper price is 1.144710 which is positive and statistically significant as the $p$ value of 0.0227 is less than 0.05 . This indicates that Copper prices have a significant long run effect on the LuSE Index. This result is logical because copper is the major export earner for Zambia so more of its export will generate more income this might stimulate investment on the stock market. This result differs with Iscan (2015) for Turkey but is similar to Kang, Hu, \& Chen (2013) for China and Chan et al. (2011) for US.

The estimated coefficient for oil is statistically insignificant. Indicating that there is no long run effect on the LuSE Index. Similar results were found by Iscan (2015). Since $50 \%$ of the variables are significant and the F statistic of 4.1692 with a significant $P$ value of 0.000 was observed it indicates that all the variables (Interest rate, REER Copper and Oil price) jointly explains some variation in the stock index. The following regression model presented below was estimated.

$$
\begin{aligned}
\text { LuSE Index }= & -0.0716+-0.00452 \text { Int }+0.007237 \text { REER } \\
& +1.1447 \text { Cop }+-0.00495 \text { oil }+\mathrm{E}
\end{aligned}
$$

From the above regression equation, it was revealed that holding Interest, REER, Copper and oil price to a constant zero, LuSE index would be -0.0716 . Furthermore, holding REER, Copper and oil price constant, a unit increase in interest rate will lead to a decrease of 0.00452 in the stock index. Holding Interest rate, Copper and oil price constant, a unit increase in REER would lead to increase in the index by 0.00723 . Holding Interest rate, REER and oil price constant, a unit increase in Copper price would lead to increase in the index by 1.1447 and Holding Interest rate, REER and copper price constant, a unit increase in Oil price would lead to decrease in the index by 0.00495 .

\section{Model Diagnostic}

To confirm the Validity of the model, the following residual diagnostic tests were done heteroskedasticity, Serial correlation and normality. The results in Table 5 Shows that all the tests were satisfied except for the normality tests, however the test for recursive cusum test showed the residues were stable. Nonetheless a study conducted by Paruolo (1997) (cited in MacDonald \& Ricci, 2003), suggested that non-normality is caused by excess kurtosis which does not affect the results. Similarly, this problem was also observed by Nordin et al. (2014).

\section{Short Run Estimation Based on Vector Error Correction Model (VECM)}

The result in Table 6 below shows that lagged by twelve the variables jointly have an impact on the stock market as the constant has a coefficient of 2.210602 which is statistically significant. Exchange rates and copper price have a short run impact on the stock market while that for oil price and interest is 
Table 6. Model Diagnostic.

\begin{tabular}{cccc}
\hline Diagnostic Tests & Test Done & Coefficient & Prob. \\
\hline Jarque Bera & Normality & 6.0468 & 0.0486 \\
Breusch pagan Godfrey & Heteroskedasticity & $\begin{array}{c}\text { R-squared } \\
15.15048\end{array}$ & 0.4406 \\
& & R-squared & 0.4437 \\
Breusch-Godfrey LM & Serial Correlation & 1.625186 & \\
\hline
\end{tabular}

Table 7. VECM Short Run Results.

\begin{tabular}{cccc}
\hline Variable & Coefficient & t-Statistic & Prob. \\
\hline C & 2.210602 & 5.997062 & 0.0000 \\
Interest Rate & -0.001425 & -0.316411 & 0.7522 \\
REER & 0.177170 & 5.174274 & 0.0000 \\
Copper Price & 8.803890 & 0.116042 & 0.0000 \\
Oil Price & -0.000514 & -0.520718 & 0.6034 \\
Error Correction Variable & -0.000167 & -6.766923 & 0.0000
\end{tabular}

negligible. This result is slightly similar to Nordin et al. (2014) who found both the long and the short run impact of the variables in the stock market, although in their study variable had an impact both jointly and individually. It is important to note that the error correction, variable has the negative sign as indicated in Table 7 above and its statistically significant confirming the presence of the long run relationship among the variables.

\section{Conclusion}

The aim of this research was to establish the influence of two macroeconomic factors (interest rate and exchange rate) of the LuSE Market returns. In addition, the study also investigated the impact of commodity prices on the LuSE market returns. The commodity prices were the price of Copper and crude oil. By employing the Auto Regression distribution lag (ARDL) bound tests, cointegration and Vector Error Correction (Model VECM) the results indicated the existence of cointegration (long run) and short run relationships between the stock price index and interest rates, exchange rates, copper and oil prices. Individually, only interest rates and copper prices were found to have a significant long term impact on the stock market. In the short run copper and exchange rates had an immediate impact on the stock market. As a result of these cointegrating relationships, there are possibilities for investors to earn excess returns. In contrast, if the market is efficient, the investors would not be able to earn any abnormal returns because the security prices will adjust rapidly to the arrival of new information, thus the current prices reflect all information about the security.

The policy implication of this study is that if the interest rate is considerably controlled by reducing, it will be of great benefit to the stock exchange market in Zambia as this will act as a demand pull way of more investors from investing in 
debt to investing in stocks.

The price of Copper was found to have a significant positive influence on the stock market index, in the long-run. This result may reflect the importance of Copper as one of the main commodities produced by the Zambia.

The results of the cointegration relationship suggest that investors on the stock can earn more returns. However, the findings are in contrast with efficient market where the returns are always influenced by the new information received and investors are unable to earn abnormal returns.

\section{References}

Alam, M. D., \& Uddin, A. S. (2009). Relationship between Interest Rate and Stock Price: Empirical Evidence from Developed and Developing Countries. International Journal of Business and Management, 4, 43-51. https://doi.org/10.5539/ijbm.v4n3p43

Bhattacharya, B., \& Mukherjee, J. (2003). Causal Relationship between Stock Market and Exchange Rate, Foreign Exchange Reserves and Value of Trade Balance: A Case Study for India. Paper Presented at the Fifth Annual Conference on Money and Finance in the Indian Economy, January 2003.

https://www.african-markets.com/en/stock-markets/luse, Accessed on 12/09/2017.

Chan, K. F., Treepongkaruma, S., Brooks, R., \& Gray, S. (2011). Asset Market Linkages: Evidence from Financial Commodity and Real Estate Assets. Journal of Banking and Finance, 35, 1415-1426. https://doi.org/10.1016/j.jbankfin.2010.10.022

Cong, R. G., Wei, Y. M., Jiao, J. L., \& Fan, Y. (2008). Relationships between Oil Price Shocks and Stock Market: An Empirical Analysis from China. Energy Policy, 36, 3544-3553. https://doi.org/10.1016/j.enpol.2008.06.006

Economic Commission for Africa (2016). Country Profile 2015-Zambia.

Erphen, I. (2014). The Relationship between Commodity Prices and Stock Price: Evidence from Turkey. SED-2014-2968.

Field A. (2005). Discovering Statistics Using SPSS. London: SAGE Publication.

Gujarati, D. (2003). Basic Econometrics. New Jersey: Mcgraw-Hill/Irwin.

Iscan, E. (2015). The Relationship between Commodity Prices and Stock Prices: Evidence from Turkey. Page 17-26.

Johansen, S. (1996) Likelihood Based Inference in Cointegrated Vector Autoregressive Models. Oxford: Oxford University Press.

Kang, J. S., Hu, J. L., \& Chen, C. W. (2013). Linkage between International Food Commodity Price and the Chinese Stock Markets. International Journal of Economics and Finance, 5, 147. https://doi.org/10.5539/ijef.v5n10p147

MacDonald, R. \& Ricci, L. (2003). Estimation of the Equilibrium Real Exchange Rate in South Africa. IMF Working Paper WP/03/44.

Mahmudul, A. (2009). Relationship between Interest Rate and Stock Price: Empirical Evidence from Developed and Developing Countries. International Journal of Business and Management, 4, 43-51. https://doi.org/10.5539/ijbm.v4n3p43

Mahmudul, A., \& Gazi, S. U. (2009) Relationship between Interest Rate and Stock Price: Empirical Evidence from Developed and Developing Countries. International Journal of Business and Management, 4, 36-42.

Mahmood, W. M., \& Mohd Dinniah, N. (2009). Stock Returns and Macroeconomics Variables: Evidence from the Six Asian-Pacific Countries. International Research Journal 
of Finance and Economics, 5, 30.

Nordin, N., Nordin, S., \& Ismail, R. (2014). The Impact of Commodity Prices, Interest Rate and Exchange Rate on Stock Market Performance: An Empirical Analysis from Malaysia. Malaysian Management Journal, 18, 39-52.

Odera, O. (2012). Theoretical Issues in the African Stock Markets and Portfolio Performance. Journal of Economics and International Finance, 4, 19-28. https://doi.org/10.5897/JEIF12.004

Rahman, A. A., Sidek, N. Z. M., \& Tafri, F. H. (2009). Macroeconomic Determinants of Malaysian Stock Market. African Journal of Business Management, 3, 95-106.

Rezitis, A. N. (2015). International Journal of Energy Economics and Policy Empirical Analysis of Agricultural Commodity Prices, Crude Oil Prices and US Dollar Exchange Rates Using Panel Data Econometric Methods. International Journal of Energy Economics and Policy, 5, 851-868.

Sichoongwe, K. (2016). Effects of Exchange Rate Volatility in the Stock Market. The Zambian Experience, 7, 114-119.

Soenen, L., \& Johonson, R. (2009). Commodity Prices and Stock Market Behaviour in South American Countries in the Short Run. Journal of Emerging Markets, Finance and Trade, 45, 69-82.

Strieborny, M., \& Olsen, A. B. (2014). Oil Price Shocks and Stock Market Returns, 1-50. https://southernafrican.news/2016/03/03/another-tough-year-for-sub-saharan-africa-st ocks/

https://www.african-markets.com/en/stock-markets/luse

Submit or recommend next manuscript to SCIRP and we will provide best service for you:

Accepting pre-submission inquiries through Email, Facebook, LinkedIn, Twitter, etc. A wide selection of journals (inclusive of 9 subjects, more than 200 journals)

Providing 24-hour high-quality service

User-friendly online submission system

Fair and swift peer-review system

Efficient typesetting and proofreading procedure

Display of the result of downloads and visits, as well as the number of cited articles

Maximum dissemination of your research work

Submit your manuscript at: http://papersubmission.scirp.org/

Or contact jfrm@scirp.org 